
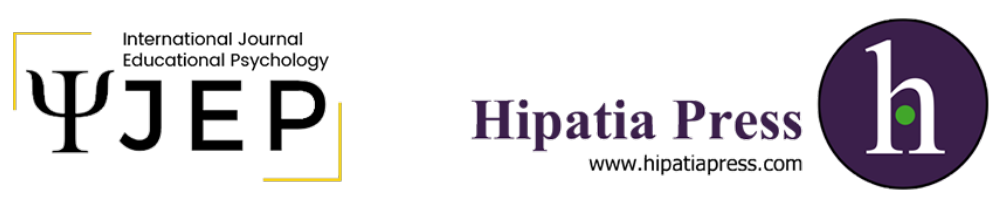

Instructions for authors, subscriptions and further details:

\title{
http://ijep.hipatiapress.com/
}

\section{Peer Aggression and Sexual Harassment among Young Adolescents in a School Context: A Comparative Study between Finland and Turkey}

Isik Zeliha Ulubas-Varpula ${ }^{1}$ Kaj Björkqvist ${ }^{1}$

${ }^{1}$ Åbo Akademi University (Finland)

Date of publication: October 24th, 2021

Edition period: October 2021 - February 2021

To cite this article: Ulubas-Varpula, I.Z, Björkqvist, K. (2021). Peer Aggression and Sexual Harassment among Young Adolescents in a School Context: A Comparative Study between Finland and Turkey. International Journal of Educational Psychology, 10(3), 199-221. http://dx.doi.org/10.17583/ijep.6853

To link this article: http://dx.doi.org/10.17583/ijep.6853

PLEASE SCROLL DOWN FOR ARTICLE

The terms and conditions of use are related to the Open Journal System and to Creative Commons Attribution License(CC-BY). 


\section{Peer Aggression and Sexual}

\section{Harassment among Young Adolescents in a School Context: A Comparative Study between Finland and Turkey}

Isik Zeliha Ulubas-Varpula

Åbo Akademi University
Kaj Björkqvist

Åbo Akademi University

\section{Abstract}

The study investigates peer aggression and sexual harassment among young adolescents in Finland and Turkey. Sex differences and the interaction effect between country of residence and sex are also examined. A questionnaire was completed by 1,747 adolescents (1, 268 from Finland, 479 from Turkey, $M_{\text {age }}$ $=14.1$ ). Six different forms of aggression (physical, verbal, indirect, cyber, verbal sexual harassment, physical sexual harassment) were examined. More adolescents from Turkey, and more boys, were found to be involved in aggression as both victims and perpetrators compared to adolescents from Finland and girls. The interaction effect was significant between country of residence and sex with being a boy from Turkey was related to having the highest involvement in cyber aggression, verbal sexual harassment, and physical sexual harassment, as both victim and perpetrator. Regarding victimization from indirect aggression, girls from Finland scored higher than Turkish girls, while boys from Turkey scored higher than Finnish boys.

Keywords: Peer aggression, sexual harassment, school, adolescence, Finland, Turkey 


\section{Agresión entre Iguales y Acoso Sexual entre Jóvenes Adolescentes en un Contexto Escolar: Un Estudio Comparativo entre Finlandia y Turquía}

Isik Zeliha Ulubas-Varpula

Abo Akademi University
Kaj Björkqvist

Abo Akademi University

\section{Resumen}

El estudio investiga la agresión entre iguales y el acoso sexual entre jóvenes adolescentes en Finlandia y Turquía. Las diferencias de sexo y el efecto de interacción entre el país de residencia y el sexo también son examinadas. Un cuestionario fue completado por 1.747 adolescentes (1.268 de Finlandia, 479 de Turquía, $M_{\text {edad }}=14,1$ ). Seis formas diferentes de agresión (física, verbal, indirecta, cibernética, acoso sexual verbal, acoso sexual físico) fueron examinadas. Se encontraron más adolescentes de Turquía, y más niños, involucrados en agresiones, tanto como víctimas y agresores, en comparación con los adolescentes de Finlandia y las niñas. El efecto de interacción fue significativo entre el país de residencia y el sexo, relacionando el ser un niño de Turquía con tener la mayor participación en ciber-agresión, acoso sexual verbal, y acoso sexual físico, tanto como víctima como agresor. En cuanto a la victimización por agresión indirecta, las niñas de Finlandia obtuvieron puntajes más altos que las niñas turcas, mientras que los niños de Turquía obtuvieron más puntajes que los niños finlandeses.

Palabras clave: Agresión entre iguales, acoso sexual, escuela, adolescencia, Finlandia, Turquía 
I

nvolvement in aggression is a risk factor for the psychosocial adjustment of adolescents (Moore et al., 2013; Nansel et al., 2004; Özdemir \& adjustment, poorer relationships with peers, and higher depression and anxiety (Nansel et al., 2004; Undheim \& Sund, 2010), while perpetrators of aggression report poorer school adjustment and higher levels of depression than non-involvers (Moore et al., 2013; Nansel et al., 2004). The studies on relationship between perpetration of aggression and depression have varying results. Some found that perpetrators had lower depression than non-involvers (Juvonen et al., 2003), while others found higher depression rates among perpetrators (Chang et al., 2013; Yen et al., 2014). Despite of varying results regarding depression, perpetration of aggression is related to low anxiety (e.g. Juvonen et al., 2003; Yen et al., 2014). Aggression is also associated with negative social relationships among the adolescents. In a study conducted in 25 countries, victims and perpetrator/victims in all countries were found to have poorer peer relationships than others, and the same was the case for perpetrators of aggression in 15 countries (Nansel et al., 2004). Involvement in aggression and sexual harassment has been found to be associated with poor attachment to peers, teachers, and parents (Doty et al., 2017; Gruber \& Fineran, 2016). However, high peer connectedness has also been found to be associated with perpetration of sexual harassment (Doty et al., 2017).

Victims of sexual harassment have been found to have higher scores on depression, anxiety, substance abuse, and self-harm, and lower school satisfaction and academic engagement than non-victim youth (Bucchianeri et al., 2014; Gruber \& Fineran, 2016). Furthermore, victimization from sexual harassment has been found to have a greater effect than bullying on adolescents' poor school outcomes (Gruber \& Fineran, 2016). Adolescents who perpetrated sexual harassment were found to have higher levels of depression, alcohol and drug abuse, and aggressive behavior than adolescents who were not involved in sexual harassment in any way (Clear et al., 2014; Lacasse \& Mendelson, 2007; Rinehart et al., 2017). Nevertheless, victims of sexual harassment report higher levels of alcohol and drug abuse than others (Clear et al., 2014; Lacasse \& Mendelson, 2007). In addition to that, adolescents are more likely to perpetrate sexual harassment if they themselves are victimized from it (Moyano et al., 2017; Munoz-Rivas et al., 2009). 


\section{Cross-national Variation in Adolescent Aggression in School Contexts}

The prevalence of involvement in aggression and sexual harassment varies in accordance with adolescents' country of residence (Craig et al., 2009; Due et al., 2005; Krahé et al., 2014; Nansel et al., 2004). According to a crossnational study among adolescents in 25 countries, the prevalence of victimization from aggression varied between $5 \%$ and $20 \%$, while perpetration of aggression varied between $3 \%$ and $20 \%$; these are highly similar results (Nansel et al., 2004). The variation between countries may partly be explained by under/over reporting of aggression in some of the countries, reflecting differing cultural values concerning aggression (Bergeron \& Schneider, 2005). According to a study comparing adolescents in 40 countries, Scandinavian countries were found to have the lowest prevalence of aggression, while Turkey was found to be one of the countries with the highest scores on victimization from aggression (Craig et al., 2009). Cross-national research on sexual harassment among adolescents is limited, and it focuses mostly on the victimization of girls. A meta-analysis of sexual aggression among European youth from 27 countries found that youth in Poland, Lithuania, the United Kingdom, and Belgium experienced more victimization from sexual aggression than youth from other European countries (Krahé et al., 2014). Among Finnish youth, 37\% of boys and 41\% of girls reported victimization from sexual harassment at least once in their lifetime (Kaltiala-Heino et al., 2018). The prevalence of frequent victimization from sexual harassment among adolescents in Finland was recently found to be around 4\% (Kaltiala-Heino et al., 2019).

Some studies have aimed at examining the reasons behind the variance in the prevalence of adolescent aggression in different countries. Two studies that were conducted in 35 and 37 countries respectively found that adolescents were more involved in aggression (as either victims or perpetrators) if they lived in a country with more income inequality (Due et al., 2009; Elgar et al., 2009). Similarly, adolescents perpetrated less aggression in countries where they receive more family and school support (Elgar et al., 2009). Moreover, according to a meta-analysis, community factors and peer influence were found to be the strongest predictors of perpetration of aggression among children and adolescents (Cook et al., 2010). Higher levels of empathy, girl density, and democratic family environment were related to lower involvement in aggression, while aggressive neighborhood, poor anger 
management, and acceptance of aggression were found to predict involvement in aggression (Chaux et al., 2009).

Nationwide anti-bullying programs and how they are implemented might reflect different outcomes regarding adolescents' aggression. All types of aggression and sexual harassment were found to decrease in schools that were part of the KiVa anti-bullying program in Finland (Salmivalli et al., 2011). A study compared two nationwide anti-bullying programs that had similar structure and methodology, one in Norway and the other in Ireland (Midthassel et al., 2009). Norwegian authorities were found to implement the program more actively than Irish authorities, where the program was carried out by psychologists, researchers, and school authorities, all receiving salary for their work, while the Irish program was carried out by teachers who volunteered for the program. Thus, the participating adolescents from Norway were found to score lower on aggression after the program than the adolescents from Ireland.

\section{Sex Differences in Aggression and its Concomitants}

A large number of studies investigating sex differences in adolescents' involvement in various forms of aggression have found that boys overall perpetrate more aggression and sexual harassment than girls (Craig et al., 2009; Espelage et al., 2012; Gruber \& Fineran, 2016). Boys have also been found to be both victims and perpetrators of direct aggression more often than girls (Barzilay et al., 2017; Lundh et al., 2014; Mehari et al., 2019). Studies have found varying results regarding sex differences on indirect aggression. According to a recent study among adolescents from ten European countries, girls reported more victimization from indirect aggression (Barzilay et al., 2017). On the other hand, some studies found that boys were more likely to become victims and perpetrators of indirect aggression than girls (Salmivalli \& Kaukiainen, 2004; Wang et al., 2015). Still, extremely indirectly aggressive groups of pupils consisted of girls only (Salmivalli \& Kaukiainen, 2004). In a review (Björkqvist, 2018), it was concluded that in proportional terms (proportional scores of total aggression scores), girls score always higher than boys on indirect aggression, as indirect aggression is their preferential style of aggression. Since the total aggression scores of boys are higher than those of girls, their scores on indirect aggression may be higher than those of girls, although it is not their preferential style. In a meta-analysis, it was found that 
girls were more likely to perpetrate cyber aggression than boys during early and mid-adolescence, while it was found to be the other way around during late adolescence (Barlett \& Coyne, 2014). Rejection by peers was found to be associated with the perpetration of physical and verbal aggression among girls (Cheng, 2009; Salmivalli et al., 2000), while it was associated with only verbal aggression among boys (Cheng, 2009; Salmivalli et al., 2000). On the other hand, the perpetration of indirect aggression was found to increase social acceptance among boys (Salmivalli et al., 2000).

Studies have found varying results regarding sex differences in sexual harassment. In Finland, girls reported more victimization from physical and verbal sexual harassment (Kaltiala-Heino et al., 2018), while in the Netherlands, boys reported more victimization from verbal sexual harassment (Timmerman, 2003). A study from Canada did not find any sex differences regarding victimization from sexual harassment, while boys were found to perpetrate more sexual harassment than girls (McMaster et al., 2002).

The aim of the current study was to compare the levels of both victimization from and perpetration of peer aggression and sexual harassment among a sample of Finnish and Turkish adolescents in a school context. Sex differences in aggression were also investigated. Sexual harassment is rarely studied in school contexts, and comparative studies with adolescent samples are limited in this area. The two countries were selected partly for reasons of convenience, but also because Finland has effective nationwide anti-bullying programs, and sex education is a part of the curriculum, while Turkey falls behind in terms of such implementations on reducing aggression among schoolchildren. For this reason, adolescents in Turkey were expected to show more involvement in aggression and sexual harassment compared to Finnish adolescents. Specifically, boys in Turkey were expected to become victimized from and to perpetrate more aggression than others.

\section{Method}

\section{Sample}

The sample consisted of young adolescents $(N=1,747,928$ girls, 746 boys and 73 other/preferred not to say) from Finland and Turkey. The participants from Finland were 1,268, while from Turkey, 479 adolescents participated in the study. The age range was 9 to 16 years $\left(M=14.1, S D=1.55, M_{\text {Finland }}=\right.$ $\left.14.71, S D=1.23, M_{\text {Turkey }}=12.57, S D=1.19\right)$. The age difference between 
Finland and Turkey was significant $\left[t_{(1747)}=32.57, p<.001, d=.002\right]$. The participants were secondary school students, including the $6^{\text {th }}, 7^{\text {th }}$ and $8^{\text {th }}$ grades in both countries, but also $5^{\text {th }}$ graders in Turkey; the age difference might be due to this circumstance.

\section{Measures}

The instrument used for measuring various types of aggression was MiniDIA-R (Österman \& Björkqvist, 2015) but some items about sexual harassment were added. Six items measured victimization from aggression and sexual harassment, and six measured the perpetration of the same. The following forms of aggression were measured: physical aggression, verbal aggression, indirect aggression, cyber aggression, verbal sexual harassment, and physical sexual harassment. Examples of each aggression form were provided in the instruction to the pupils in order to avoid misperceptions. Translations of the questionnaire into Turkish and Finnish were made by translators who were fluent in the source language, and native speakers of the target language (Beaton et al., 2000). In addition, the questionnaire was backtranslated into the source language in order to eliminate possible inconsistencies or conceptual errors. The choices of responses were on a fivepoint scale ranging from $0=$ never to $4=$ very often. The different types of aggression can be analyzed separately or added together as a total score of victimization or perpetration of aggression. In the present report, they were analyzed separately. If added together, the reliability score for victimization from aggression and sexual harassment was $\alpha=.84$, and for perpetration of aggression and sexual harassment it was $\alpha=.82$. Since the sample was large and the percentage of missing data was low $(<5 \%)$, missing data were handled with list-wise deletion.

\section{Procedure}

The data were collected with an online questionnaire in Finland, and with both an online and a paper-and-pencil questionnaire in Turkey. The data from Finland were collected from the Ostrobothnian region in Western Finland, which is bilingual, as both Finnish and Swedish are spoken in the area. The questionnaire was provided in both spoken languages. The data from Turkey were collected from four different regions, namely the Aegean, Central Anatolia, Marmara, and Southeast Anatolia. 
With respect to statistical analyses, the data were foremost analyzed with multiple analysis of variance (MANOVA) and multiple analysis of covariance (MANCOVA). Pearson's correlations were also used. Due to doubtful homogeneity of variance of some variables, the data were in addition analyzed with a nonparametric test, Mann-Whitney's U.

\section{Ethical considerations}

The study followed the guidelines of the Finnish Advisory Board on Research Integrity (2012) for responsible conduct of research. Required permissions were obtained from school officials or municipalities, as well as consent from parents/legal guardians and the adolescents themselves. Anonymity, confidentiality and voluntary attendance were principles observed in the conduction of the study. Some school officials in Turkey who were approached for participation in the study rejected the implementation of the questionnaire due to the existing items about sexual harassment.

\section{Results}

Correlations between the dependent variables of the study are presented in Table 1. As the table shows, all of the variables (scales) correlated significantly with each other. This was the case for both variables measuring victimization and perpetration of aggression and sexual harassment.

\section{Table 1}

Correlation Coefficients for Victimization below the Diagonal, and for Perpetration above the Diagonal $(N=1,747)$

\begin{tabular}{|c|c|c|c|c|c|c|}
\hline & 1. & 2. & 3. & 4. & 5. & 6. \\
\hline 1. Physical aggression & & $.63 * * *$ & $.46^{* * *}$ & $44 * * *$ & $.43 * * *$ & $.34 * * *$ \\
\hline 2. Verbal aggression & $.55^{* * *}$ & & $.53 * * *$ & $.44 * * *$ & $.36^{* * *}$ & $.29 * * *$ \\
\hline 3. Indirect aggression & $.42 * * *$ & $.58 * * *$ & & $.46^{* * *}$ & $.36 * * *$ & $.33 * * *$ \\
\hline 4. Cyber aggression & $.42 * * *$ & $.47 * * *$ & $.53 * * *$ & & $.55 * * *$ & $.47 * * *$ \\
\hline $\begin{array}{l}\text { 5. Verbal sexual } \\
\text { harassment }\end{array}$ & $.41 * * *$ & $.42 * * *$ & $.43 * * *$ & $.52 * * *$ & & $.61 * * *$ \\
\hline $\begin{array}{l}\text { 6. Physical sexual } \\
\text { harassment }\end{array}$ & $.40 * * *$ & $.37 * * *$ & $.37 * * *$ & $49 * * *$ & $.64 * * *$ & \\
\hline
\end{tabular}




\section{The Effect of Country of Residence on Victimization from and Perpetration of Aggression}

A two-way MANCOVA was performed with age as covariate, country of residence and sex as independent variables, and victimization from aggression and sexual harassment as dependent variables. The results are presented in Table 2 and Figures 1 and 2. As the table indicates, the effect of country of residence on four variables of victimization (physical aggression, cyber aggression, verbal sexual harassment, and physical sexual harassment) was significant, with adolescents from Turkey scoring higher on all four (Fig. 1). The effect of sex was also significant, on the same four variables (Fig. 2). There were interaction effects between country of residence and sex on five variables (physical, indirect, and cyber aggression; and both physical and verbal sexual harassment). The boys from Turkey stood out with their high scores. On indirect aggression, girls from Finland had higher scores than girls from Turkey.

\section{Table 2}

Results from a Multivariate Analysis of Covariance (MANCOVA) with Age as Covariate, Country and Sex as Independent Variables, and Victimization from Aggression and Sexual Harassment as Dependent Variables $(N=1,597)$, cf. Figures 1 and 2.

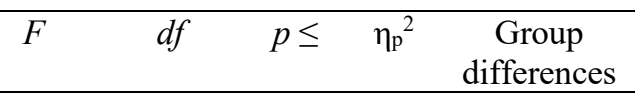

\begin{tabular}{lccccc}
\hline $\begin{array}{l}\text { Effect of the Covariate (age) } \\
\text { Multivariate analysis } \\
\text { Effect of Country }\end{array}$ & 5.23 & 6,1598 & .001 & .019 & \\
$\quad$ Multivariate analysis & 18.05 & 6,1598 & .001 & .063 & \\
$\quad$ Univariate analyses & & & & & \\
$\quad$ Physical aggression & 30.97 & 1,603 & .001 & .019 & $\mathrm{~T}>\mathrm{F}^{*}$ \\
$\quad$ Verbal aggression & 0.44 & “ & $n s$ &. & \\
Indirect aggression & 0.79 & “ & $n s$ &. & \\
Cyber aggression & 37.00 & “ & .001 & .023 & $\mathrm{~T}>\mathrm{F}$ \\
$\quad$ Verbal sexual harassment & 38.50 & “ & .001 & .023 & $\mathrm{~T}>\mathrm{F}$ \\
$\quad$ Physical sexual harassment & 23.52 & “ & .001 & .014 & $\mathrm{~T}>\mathrm{F}$ \\
\hline
\end{tabular}


Table 2 (continued)

Effect of Sex

Multivariate analysis

Univariate analyses

Physical aggression

Verbal aggression

Indirect aggression

Cyber aggression

Verbal sexual harassment

Physical sexual harassment

Interaction effect Country $x$ Sex

Multivariate analysis

Univariate analyses

Physical aggression

Verbal aggression

Indirect aggression

Cyber aggression

Verbal sexual harassment

Physical sexual harassment

11.11

6,1598

.001

.040

40.47

3.01

0.92

7.15

9.51

14.93
$.001 \quad .025$

ns

ns

$.008 \quad .004$

$.002 \quad .006$

$.001 \quad .009$

$\hat{0}>q$

$\hat{0}>$ ㅇ

$\hat{0}>$ q

$6.30 \quad 6,1598 \quad .001 \quad .023$

$\begin{array}{llll}3.99 & 1,1603 & .046 \quad .002\end{array}$

0.58

15.87

“

$n s$

“ $\quad .001 \quad .010$

17.48

“

$.001 \quad .011$

21.10

$\begin{array}{lll}\text { “ } & .001 \quad .013\end{array}$

15.58

$.001 \quad .010$

$* \mathrm{~T}=$ Turkey, $\mathrm{F}=$ Finland

A two-way MANOVA was performed with country of residence and sex as independent variables, and the measurements of perpetration of aggression and sexual harassment as dependent variables. Since age was not found to have a significant effect on perpetration of aggression, it was not included as a covariate in this case. The results are presented in Table 3 and Figures 3 and 4. As the table indicates, the effect of country was significant on all variables of perpetration, with adolescents from Turkey scoring higher on all of them (Fig. 3).

There was a significant interaction effect on four variables of victimization with boys from Turkey scoring highest in cyber aggression, verbal sexual harassment, and physical sexual harassment, while the perpetration of indirect aggression was found to be higher among girls from Finland, and among boys from Turkey. The interaction effect was significant on all variables of 
perpetration from aggression, with boys from Turkey scoring the highest in all types of perpetration of aggression.

\section{Figure 1}

Mean scores for victimization from six types of aggression and sexual harassment, according to country of residence $(N=1,597)$. For significant differences, $c f$. Table 2.

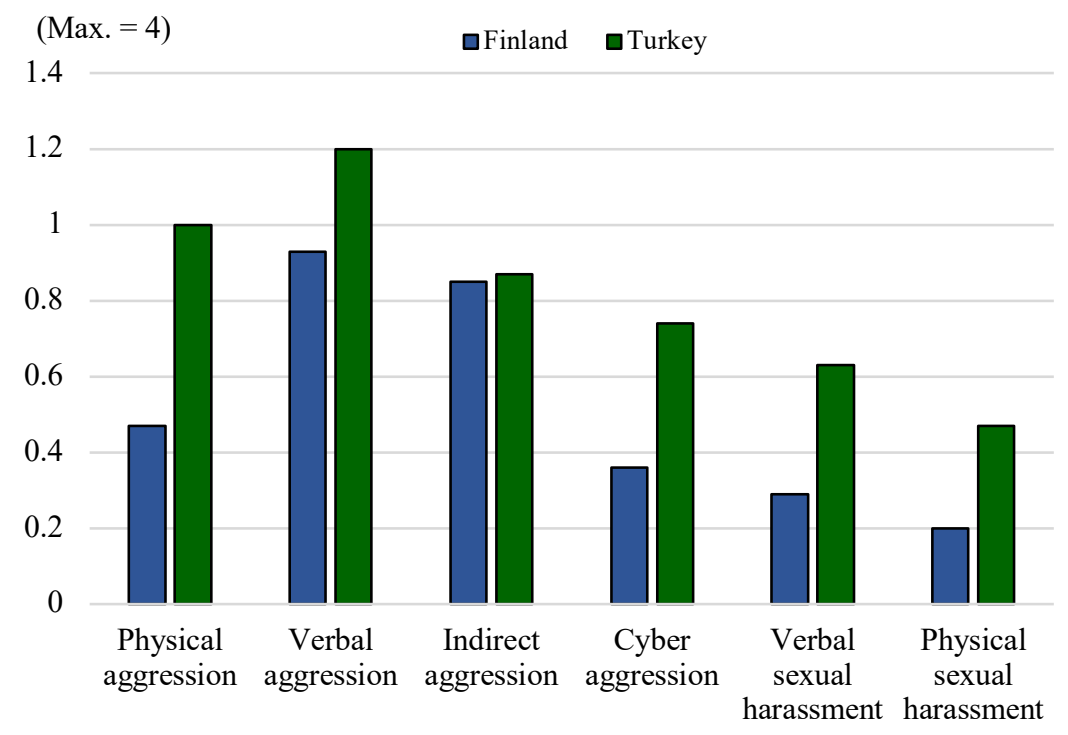




\section{Figure 2}

Mean scores for victimization from six types of aggression and sexual harassment, according to sex $(N=1,597)$. For significant differences, $c f$. Table 2.

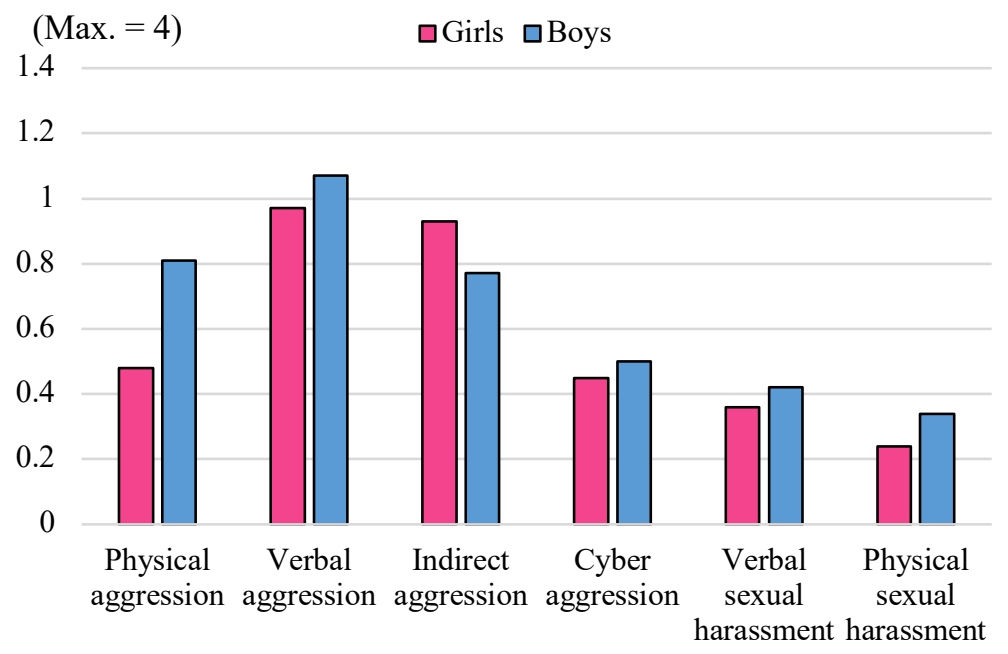

\section{Table 3}

Results from a Multivariate Analysis of Variance (MANOVA) with Country and Sex as Independent Variables, and Perpetration of Aggression and Sexual Harassment as Dependent Variables $(N=1,597)$, cf. Figures 3 and 4 .

\begin{tabular}{lccccc}
\hline & $F$ & $d f$ & $p \leq$ & $\eta_{\mathrm{p}}{ }^{2}$ & $\begin{array}{c}\text { Group } \\
\text { differences }\end{array}$ \\
\hline $\begin{array}{l}\text { Effect of Country } \\
\text { Multivariate analysis }\end{array}$ & 15.76 & 6,1591 & .001 & .056 & \\
Univariate analyses & & & & & \\
$\quad$ Physical aggression & 11.58 & 1,1596 & .001 & .007 & $\mathrm{~T}>\mathrm{F}^{*}$ \\
$\quad$ Verbal aggression & 38.49 & “ & .001 & .024 & $\mathrm{~T}>\mathrm{F}$ \\
$\quad$ Indirect aggression & 14.37 & “ & .001 & .009 & $\mathrm{~T}>\mathrm{F}$ \\
Cyber aggression & 26.96 & “ & .001 & .017 & $\mathrm{~T}>\mathrm{F}$ \\
$\quad$ Verbal sexual harassment & 74.20 & “ & .001 & .044 & $\mathrm{~T}>\mathrm{F}$ \\
$\quad$ Physical sexual harassment & 34.87 & “ & .001 & .021 & $\mathrm{~T}>\mathrm{F}$
\end{tabular}


Table 3 (continued)

Effect of Sex

Multivariate analysis

20.77

$6,1591 \quad .001 \quad .073$

Univariate analyses

Physical aggression

Verbal aggression

Indirect aggression

Cyber aggression

Verbal sexual harassment

Physical sexual harassment

55.6

17.53

7.62

38.01

74.18

1,1596

$.001 \quad .034$

$\hat{0}>q$

$\begin{array}{lll}\cdots & .001 & .011\end{array}$

“ $\quad .006 \quad .005$

$\hat{0}>$ +

80.85

$\begin{array}{lll}\text { “ } & .001 & .023\end{array}$

$\hat{0}>$ 舟

“ $\quad .001 \quad .044$

$\hat{0}>$ q

î $>$ +

80.85

“

$.001 \quad .048$

$0>q$

Interaction effect Country $x$ Sex

Multivariate analysis

$14.34 \quad 6,1591 \quad .001 \quad .051$

Univariate analyses

Physical aggression

Verbal aggression

Indirect aggression

$3.02 \quad 1,1596 \quad n s$

1.16

“"

ns

21.34

“

$.001 \quad .013$

Cyber aggression

7.25

$\begin{array}{lll}\text { ، } & .007 & .005\end{array}$

Verbal sexual harassment

43.48

$\begin{array}{lll}\text { “ } & .001 & .027\end{array}$

Physical sexual harassment

38.39

$\begin{array}{lll}\text { “ } & .001 \quad .023\end{array}$ 


\section{Ulubas \& Björkqvist - Peer aggression \& sexual harassment}

\section{Figure 3}

Mean scores for perpetration of six types of aggression and sexual harassment, according to country of residence $(N=1,597)$. For significant differences, $c f$. Table 3.

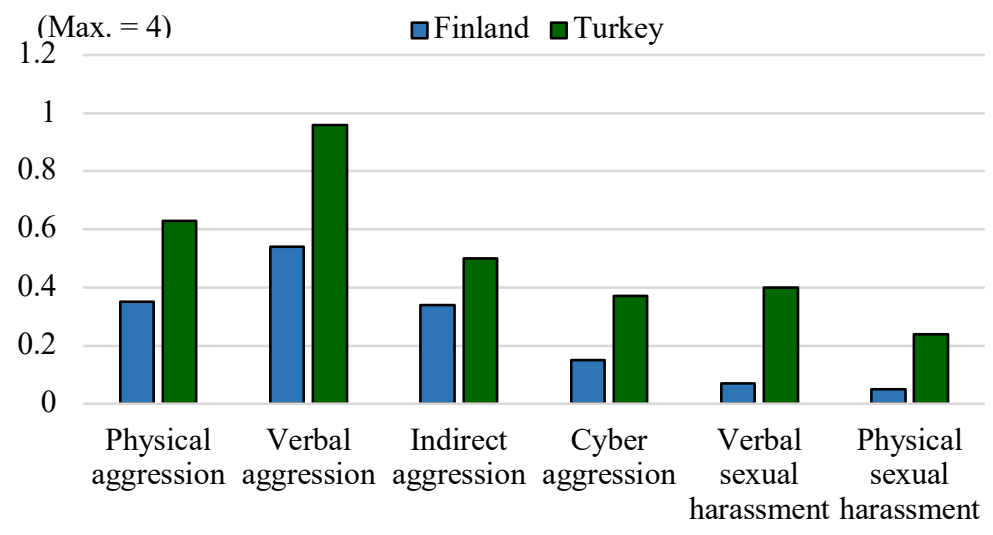

\section{Figure 4}

Mean scores of perpetration of six types of aggression and sexual harassment, according to sex $(N=1,597)$. For significant differences, cf. Table 3.

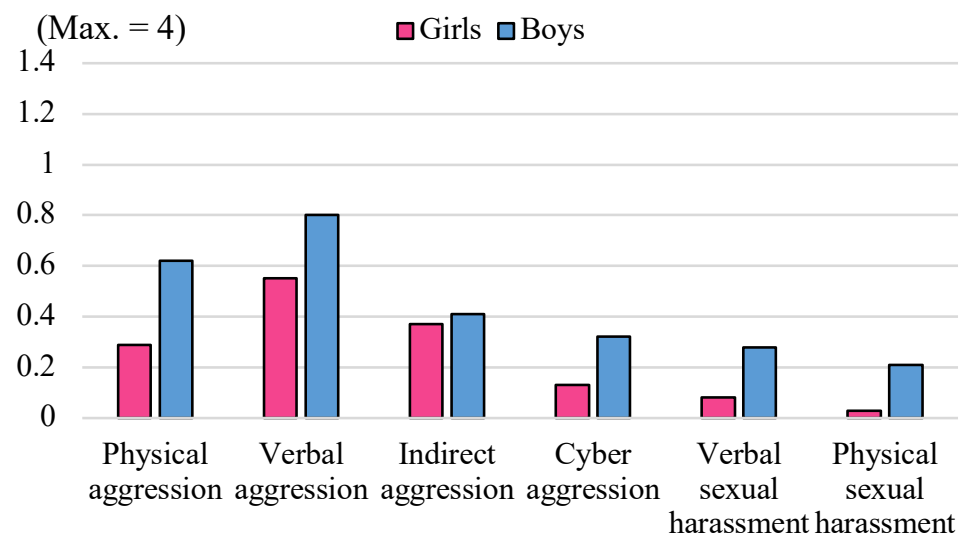


Because a Levene's test for the measurement of the homogeneity of variance indicated that the variables did not fully satisfy the criteria of homogeneity between them, analyses were also conducted with a non-parametric test, Mann-Whitney's U for two independent samples, which is not sensitive to this problem.

According to the Mann-Whitney's $\mathrm{U}$ with the significance level set at $p<$ .05 , there was a significant difference between the Finnish and the Turkish adolescents on all variables of both victimization from and perpetration of aggression and sexual harassment. Note that according to the MANCOVA, there was not a significant difference between the countries on two variables, victimization from verbal aggression and indirect aggression.

When sex differences were analyzed with Mann-Whitney's U, a significant difference was observed on three of the victimization variables: physical aggression, indirect aggression, and physical sexual harassment, and five of the perpetration variables: physical aggression, verbal aggression, cyber aggression, verbal sexual harassment, and physical sexual harassment.

Whether one should trust the results from the parametric or the nonparametric tests more is a moot point. When the criteria for the homogeneity of variance are not fulfilled, and when large sample variances are associated with smaller group sizes, the $F$-statistic may be biased and the significance level may be underestimated (Field, 2013). On the other hand, MannWhitney's U does not correct for multiple analyses, which MANOVA does, and is therefore more likely to make so called type 1 errors. The present authors are of the opinion that the MANOVA and MANCOVA results in this case may perhaps present a slightly truer picture of the reality. However, it should be noted that the results of the parametric and the non-parametric tests are very much in concert with each other.

\section{Discussion}

Comparative studies on aggression and sexual harassment enable the identification of cross-national similarities and differences among youth. In the current study, the aim was to compare adolescents' aggression and sexual harassment according to country of residence and sex, and the interaction effect between these independent variables was also investigated.

Country of residence was significantly related to victimization from aggression and sexual harassment, and differences between the two countries 


\section{Ulubas \& Björkqvist - Peer aggression \& sexual harassment}

regarding victimization were found. Adolescents in Turkish schools were found to become victimized more from most types of aggression (according to the MANCOVA) and from all types of aggression (according to the MannWhitney's U) than adolescents in Finnish schools. The difference might be due to the quality of relationship with peers and respectful/fair school environment, since these have been found to predict adolescent aggression (Cook et al., 2010). Peer competition is more prevalent in Turkey than in Finland (p.121, OECD, 2019), a fact which might reduce the quality of peer relations. From another point of view, the difference might also reflect varying cultural values between the two countries (Bergeron \& Schneider, 2005).

Scores of victimization from sexual harassment were also higher among adolescents from Turkey. The results suggest that in Turkey, an effective nation-wide prevention program against bullying should have its focus on victimization from physical and cyber aggression, and on sexual harassment. Moreover, the results might reflect inadequate communication patterns in the families (Gruber \& Fineran, 2016). Victimization from sexual harassment might even in some cases be attempted to be covered up for the sake of family reputation, which makes the situation not only more traumatic for the victims, but it might also make them reluctant to talk about similar incidents to their parents and teachers in the future. In Finland, parents are provided information about adolescents' sex education by the Ministry of Health, which is perceived positively (Lottes \& Kontula, 2000). On the other hand, in Turkey, sexual education is not included in the school curriculum. However, an increasing number of people in Turkey are becoming aware of the existence of sexual harassment towards children, and several cases have been reported in media, encouraging child victims to report such incidents (Bulut, 2016). In Finland, children receive sex education already in primary school (Kontula, 2010), and the education includes also information about sexual harassment. Such implementations are not likely to occur in Turkey in a foreseeable future.

The perpetration of aggression and sexual harassment was found to be related to country of residence, and the differences were significant in all types of perpetration. To our knowledge, this is the first study that compared sexual harassment among adolescents in Finland and Turkey. The results on perpetration of aggression were in line with the study by Craig and colleagues (2009). Community indicators such as neighborhood, lower socio-economic factors (Cook et al., 2010), higher income inequality (Due et al., 2009; Elgar 
et al., 2009), or less family/peer support (Elgar et al., 2009) might explain the higher perpetration rates among adolescents from Turkey.

The findings on sex differences in victimization from physical aggression support previous findings (Barzilay et al., 2017; Lundh et al., 2014). Boys were found to experience more victimization from verbal and cyber aggression, which is in line with some previous studies (Aricak et al., 2008; Barzilay et al., 2017; Lundh et al., 2014). Boys also reported more victimization from verbal and physical sexual harassment, which is partly congruent with previous findings (Timmerman, 2003). Similarly, sex differences on victimization from indirect aggression were also insignificant. Scores on victimization from indirect and cyber aggression, as well as verbal and physical sexual harassment, were higher among boys from Turkey, but among girls from Finland. The mean difference between the mentioned aggression types was particularly high among boys and girls in Turkey.

Boys were overall found to perpetrate more aggression and sexual harassment than girls, as in line with previous studies (Barlett \& Coyne, 2014; Craig et al., 2009; Espelage et al., 2012; Gruber \& Fineran, 2016; Timmerman, 2003). There was also a significant sex difference on almost all types of perpetration. No sex difference was found on the perpetration of indirect aggression. It is known from previous research that sex differences in indirect aggression might vary cross-nationally (Björkqvist, 2018). Regardless of country of residence, boys show higher externalizing behavior, which has been found to predict perpetration of aggression (Cook et al., 2010). Further research is needed to address the association between sex and the aforementioned variables.

Further research might also investigate the effect of respectful/fair school environment and peer relations on victimization and perpetration in the two countries. Similarly, whether sex education has a mitigating effect on sexual harassment could be investigated. Moreover, future research might focus on differing cultural norms about peer aggression in the countries being studied.

Some limitations of the study should be mentioned. First, some authors recommend that translations are made by native translators of the target language that are not the authors themselves (Borsa et al., 2012). In the current study, the translation of the measurement tool to Turkish was made by the first author who is a native speaker, due to lack of resources. The authors tried to 


\section{Ulubas \& Björkqvist - Peer aggression \& sexual harassment}

limit this possibility by adapting the current questionnaire after a synthesis and evaluation of several translations of similar measurement tools.

Second, it is possible that an underreporting of sexual harassment might have occurred, especially among the adolescents from Turkey, because sexual harassment is a taboo and a topic which is not spoken freely about in the country. The researchers tried to overcome this problem as much as possible by emphasizing the anonymity and confidentiality of the study during the data collection. Another limitation was that the Turkish data were collected from five different regions, while Finnish data all were from one region; this fact might affect the representability of the Finnish sample. On the other hand, unlike in Turkey, regional disparities in terms of school contexts are very low in Finland.

Overall, the current study compares adolescents' involvement in aggression and sexual harassment in two countries with standard methodology and measures. It draws attention to similarities and disparities in different forms of aggression and sexual harassment in Finland and Turkey. The results support to a large extent previous research on sex differences, but they also stress the interaction effect between the two independent variables (country and sex) in question. Moreover, the findings reflect cross-cultural aspects of the nature of adolescent aggression. Adolescents' involvement in aggression and sexual harassment is a serious risk factor for their mental well-being, and the issue should be addressed cross-nationally.

\section{References}

Aricak, T., Siyahhan, S., Uzunhasanoglu, A., Saribeyoglu, S., Ciplak, S., Yilmaz, N., \& Memmedov, C. (2008). Cyberbullying among Turkish adolescents. Cyberpsychology \& Behavior, 11, 253-261.

https://doi.org/10.1089/cpb.2007.0016

Baldry, A. C., Sorrentino, A., \& Farrington, D. P. (2019). Post-traumatic stress symptoms among Italian preadolescents involved in school and cyber bullying and victimization. Journal of Child and Family Studies, 28, 2358-2364. https://doi.org/10.1007/s10826-018-1122-4

Barlett, C., \& Coyne, S. M. (2014). A meta-analysis of sex differences in cyber-bullying behavior: The moderating role of age. Aggressive Behavior, 40, 474-488. https://doi.org/10.1002/ab.21555 
Barzilay, S., Klomek, A. B., Apter, A., Carli, V., Wasserman, C., Hadlaczky, G., ... Kereszteny, A. (2017). Bullying victimization and suicide ideation and behavior among adolescents in Europe: A 10country study. Journal of Adolescent Health, 61, 179-186.

https://doi.org/10.1016/j.jadohealth.2017.02.002

Beaton, D. E., Bombardier, C., Guillemin, F., \& Ferraz, M. B. (2000).

Guidelines for the process of cross-cultural adaptation of self-report measures. Spine, 25, 3186-3191.

Bergeron, N., \& Schneider, B. H. (2005). Explaining cross-national differences in peer-directed aggression: A quantitative synthesis. Aggressive Behavior, 31, 116-137. https://doi.org/10.1002/ab.20049 Björkqvist, K. (2018). Gender differences in aggression. Current Opinion in Psychology, 19, 30-42. https://doi.org/10.1016/j.copsyc.2017.03.030

Borsa, J. C., Damasio, B. F., \& Bandeira, D. R. (2012). Cross-cultural adaptation and validation of psychological instruments: some considerations. Paidéia (Ribeirão Preto): Cadernos de Psicologia e Educação, 22, 423-432. http://hdl.handle.net/10183/98929

Bucchianeri, M. M., Eisenberg, M. E., Wall, M. M., Piran, N., \& NeumarkSztainer, D. (2014). Multiple types of harassment: Associations with emotional well-being and unhealthy behaviors in adolescents. Journal of Adolescent Health, 54, 724-729.

https://doi.org/10.1016/j.jadohealth.2013.10.205

Bulut, S. (2016). The problem of defining sexual abuse in children. Turkish Psychological Counseling and Guidance Journal, 3 (28).

http://turkpdrdergisi.com/index.php/pdr/article/view/276

Chang, F., Lee, C., Chiu, C., Hsi, W., Huang, T., \& Pan, Y. (2013).

Relationships among cyberbullying, school bullying, and mental health in Taiwanese adolescents. Journal of School Health, 83, 454-462. https://doi.org/10.1111/josh.12050

Chaux, E., Molano, A., \& Podlesky, P. (2009). Socio-economic, sociopolitical and socio-emotional variables explaining school bullying: a country-wide multilevel analysis. Aggressive Behavior, 35, 520-529. https://doi.org/10.1002/ab.20320

Cheng, C. (2009). No blood means less harm?: Relational aggression and peer rejection in adolescence. Bulletin of Educational Psychology, 40, 511-528. http://dx.doi.org/10.6251\%2fBEP.20080908 
Clear, E. R., Coker, A. L., Cook-Craig, P. G., Bush, H. M., Garcia, L. S., Williams, C. M., ... \& Fisher, B. S. (2014). Sexual harassment victimization and perpetration among high school students. Violence against Women, 20, 1203-1219.

https://doi.org/10.1177\%2F1077801214551287

Connolly, J., Josephson, W., Schnoll, J., Simkins-Strong, E., Pepler, D., MacPherson, A., . . . Jiang, D. (2015). Evaluation of a youth-led program for preventing bullying, sexual harassment, and dating aggression in middle schools. The Journal of Early Adolescence, 35, 403-434.

https://doi.org/10.1177\%2F0272431614535090

Cook, C. R., Williams, K. R., Guerra, N. G., Kim, T. E., \& Sadek, S. (2010). Predictors of bullying and victimization in childhood and adolescence: A meta-analytic investigation. School Psychology Quarterly, 25, 65-83. https://doi.org/10.1037/a0020149

Craig, W., Harel-Fisch, Y., Fogel-Grinvald, H., Dostaler, S., Hetland, J., Simons-Morton, B., . . . Pickett, W. (2009). A cross-national profile of bullying and victimization among adolescents in 40 countries.

International Journal of Public Health, 54, 216-224.

https://doi.org/10.1007/s00038-009-5413-9

Doty, J., Gower, A., Rudi, J., McMorris, B., \& Borowsky, I. (2017). Patterns of bullying and sexual harassment: Connections with parents and teachers as direct protective factors. Journal of Youth and Adolescence, 46, 22892304. https://doi.org/10.1007/s10964-017-0698-0

Due, P., Holstein, B. E., Lynch, J., Diderichsen, F., Gabhain, S. N., Scheidt, P., \& Currie, C. (2005). Bullying and symptoms among school-aged children: International comparative cross sectional study in 28 countries. European Journal of Public Health, 15, 128-132.

https://doi.org/10.1093/eurpub/cki105

Due, P., Merlo, J., Harel-Fisch, Y., Damsgaard, M. T., soc, M. s., Holstein, B. E., . . Gabhainn, S. N. (2009). Socioeconomic inequality in exposure to bullying during adolescence: A comparative, cross-sectional, multilevel study in 35 countries. American Journal of Public Health, 99, 907-914.

https://ajph.aphapublications.org/doi/abs/10.2105/AJPH.2008.139303

Elgar, F. J., Craig, W., Boyce, W., Morgan, A., \& Vella-Zarb, R. (2009).

Income inequality and school bullying: Multilevel study of adolescents in 
37 countries. Journal of Adolescent Health, 45, 351-359.

https://doi.org/10.1016/j.jadohealth.2009.04.004

Espelage, D. L., Basile, K. C., \& Hamburger, M. E. (2012). Bullying

perpetration and subsequent sexual violence perpetration among middle school students. Journal of Adolescent Health, 50, 60-65.

https://doi.org/10.1016/j.jadohealth.2011.07.015

Field, A. (2013). Discovering statistics using SPSS (4th ed.). New York:

Sage.

Gruber, J., \& Fineran, S. (2016). Sexual harassment, bullying, and school outcomes for high school girls and boys. Violence Against Women, 22, 112-133. https://doi.org/10.1177\%2F1077801215599079

Juvonen, J., Graham, S., \& Schuster, M. A. (2003). Bullying among young adolescents: The strong, the weak, and the troubled. Pediatrics, 112, 1231-1237. https://doi.org/10.1542/peds.112.6.1231

Kaltiala-Heino, R., Lindberg, N., Fröjd, S., Haravuori, H., \& Marttunen, M. (2019). Adolescents with same-sex interest: Experiences of sexual harassment are more common among boys. Health Psychology and Behavioral Medicine, 7, 105-127.

https://doi.org/10.1080/21642850.2019.1598864

Kaltiala-Heino, R., Savioja, H., Fröjd, S., \& Marttunen, M. (2018).

Experiences of sexual harassment are associated with the sexual behavior of 14-to 18-year-old adolescents. Child Abuse \& Neglect, 77, 46-57. https://doi.org/10.1016/j.chiabu.2017.12.014

Kontula, O. (2010). The evolution of sex education and students' sexual knowledge in Finland in the 2000s. Sex Education: The ABC of Sex and Relationships Education: Approaches, Benefits, Constraints, 10, 373386. https://doi.org/10.1080/14681811.2010.515095

Krahé, B., Tomaszewska, P., Kuyper, L., \& Vanwesenbeeck, I. (2014). Prevalence of sexual aggression among young people in Europe: A review of the evidence from $27 \mathrm{EU}$ countries. Aggression and Violent Behavior, 19, 545-558. https://doi.org/10.1016/j.avb.2014.07.005

Lacasse, A., \& Mendelson, M. J. (2007). Sexual Coercion among adolescents. Journal of Interpersonal Violence, 22, 424-437. https://doi.org/10.1177\%2F0886260506297027

Lottes, I., \& Kontula, O. (2000). New views on sexual health: The case of Finland. (Series D, 37). The Population Research Institute \& The Family 
Federation of Finland. http://vaestoliitto-fi-

bin.directo.fi/@Bin/6af7ae5b75c1c3b1fb3079efa3fd8a90/1596199933/ap plication/pdf/320403/New\%20views\%20on\%20Sexualhealth_1.pdf

Lundh, L., Daukantaité, D., \& Wångby-Lundh, M. (2014). Direct and indirect aggression and victimization in adolescents - associations with the development of psychological difficulties. BMC Psychology, 2:43. https://doi.org/10.1186/s40359-014-0043-2

McMaster, L. E., Connolly, J., Pepler, D., \& Craig, W. M. (2002). Peer to peer sexual harassment in early adolescence: A developmental perspective. Development and Psychopathology, 14, 91-105. https://doi.org/10.1017/S0954579402001050

Mehari, K. R., Waasdorp, T. E., \& Leff, S. S. (2019). Measuring relational and overt aggression by peer report: A comparison of peer nominations and peer ratings. Journal of School Violence, 18, 362-374. https://doi.org/10.1080/15388220.2018.1504684

Midthassel, U. V., Minton, S. J., \& O'Moore, A. M. (2009). Conditions for the implementation of anti-bullying programmes in Norway and Ireland: A comparison of contexts and strategies. Compare: A Journal of Comparative and International Education, 39, 737-750. https://doi.org/10.1080/03057920902772081

Moore, S. E., Norman, R. E., Sly, P. D., Whitehouse, A. J. O., Zubrick, S. R., \& Scott, J. (2013). Adolescent peer aggression and its association with mental health and substance use in an Australian cohort. Journal of Adolescence, 37, 11-21.

https://doi.org/10.1016/j.adolescence.2013.10.006

Moyano, N., Monge, F. S., \& Sierra, J. C. (2017). Predictors of sexual aggression in adolescents: Gender dominance vs. rape supportive attitudes. The European Journal of Psychology Applied to Legal Context, 9, 25-31. https://doi.org/10.1016/j.ejpal.2016.06.001

Munoz-Rivas, M. J., Grana, J. L., O'Leary, K. D., \& González, M. P. (2009). Prevalence and predictors of sexual aggression in dating relationships of adolescents and young adults. Psicothema, 21, 234-240.

http://www.psicothema.es/pdf/3620.pdf

Nansel, T. R., Craig, W., Overpeck, M. D., Saluja, G., \& Ruan, W. J. (2004). Cross-national consistency in the relationship between bullying behaviors 
and psychosocial adjustment. Archives of Pediatrics \& Adolescent Medicine, 158, 730-736. http://dx.doi.org/10.1001/archpedi.158.8.730 OECD (2019). PISA 2018 Results (Volume III): What School Life Means for Students' Lives. PISA, OECD Publishing, Paris.

https://doi.org/10.1787/acd78851-en

OECD (2009). Society at a Glance 2009: OECD Social Indicators, OECD Publishing, Paris, https://doi.org/10.1787/soc glance-2008-en

Österman, K., \& Björkqvist, K. (2015). The Revised Mini Direct and Indirect Aggression Inventory (Mini-DIA-R). Vasa, Finland: Dept. of Social Sciences, Åbo Akademi University.

Özdemir, M., \& Stattin, H. (2011). Bullies, victims, and bully-victims: A longitudinal examination of the effects of bullying-victimization experiences on youth well-being. Journal of Aggression, Conflict and Peace Research, 3, 97-102. https://doi.org/10.1108/17596591111132918 Rinehart, S. J., Espelage, D. L., \& Bub, K. L. (2017). Longitudinal effects of gendered harassment perpetration and victimization on mental health outcomes in adolescence. Journal of Interpersonal Violence, 1-20. https://doi.org/10.1177\%2F0886260517723746

Salmivalli, C., Kärnä, A., \& Poskiparta, E. (2011). Counteracting bullying in Finland: The KiVa program and its effects on different forms of being bullied. International Journal of Behavioral Development, 35, 405-411. https://doi.org/10.1177/0165025411407457

Salmivalli, C., \& Kaukiainen, A. (2004). "Female aggression" revisited: Variable-and person-centered approaches to studying gender differences in different types of aggression. Aggressive Behavior, 30, 158-163. https://doi.org/10.1002/ab.20012

Salmivalli, C., Kaukiainen, A., \& Lagerspetz, K. (2000). Aggression and sociometric status among peers: Do gender and type of aggression matter? Scandinavian Journal of Psychology, 41, 17-24. https://doi.org/10.1111/1467-9450.00166

Timmerman, G. (2003). Sexual harassment of adolescents perpetrated by teachers and by peers: An exploration of the dynamics of power, culture, and gender in secondary schools. Sex Roles, 48, 231-244.

https://doi.org/10.1023/A:1022821320739

Turner, M. G., Exum, M. L., Brame, R., \& Holt, T. J. (2013). Bullying victimization and adolescent mental health: General and typological 
effects across sex. Journal of Criminal Justice, 4, 53-59. https://doi.org/10.1016/j.jcrimjus.2012.12.005

Undheim, A., \& Sund, A. (2010). Prevalence of bullying and aggressive behavior and their relationship to mental health problems among 12- to 15-year-old Norwegian adolescents. European Child \& Adolescent Psychiatry, 19, 803-811. https://doi.org/10.1007/s00787-010-0131-7 Wang, S., Zhang, W., Li, D., Yu, C., Zhen, S., \& Huang, S. (2015). Forms of aggression, peer relationships, and relational victimization among Chinese adolescent girls and boys: Roles of prosocial behavior. Frontiers in Psychology, 6:1264. https://doi.org/10.3389/fpsyg.2015.01264

Ybrandt, H., \& Armelius, K. (2010). Peer aggression and mental health problems. School Psychology International, 31, 146-163.

https://doi.org/10.1177\%2F0143034309352267

Yen, C., Yang, P., Wang, P., Lin, H., Liu, T., Wu, Y., \& Tang, T. (2014). Association between school bullying levels/types and mental health problems among Taiwanese adolescents. Comprehensive Psychiatry, 55, 405-413. https://doi.org/10.1016/j.comppsych.2013.06.001

Zimmer-Gembeck, M., Trevaskis, S., Nesdale, D., \& Downey, G. (2014). Relational victimization, loneliness and depressive symptoms: Indirect associations via self and peer reports of rejection sensitivity. Journal of Youth and Adolescence, 43, 568-582. https://doi.org/10.1007/s10964013-9993-6

Isik Z Ulubas-Varpula is a $\mathrm{PhD}$ candidate in Developmental Psychology at Åbo Akademi University, Finland.

ORCID ID: https://orcid.org/0000-0002-1321-023X

Kaj Björkqvist is professor emeritus of Developmental Psychology at Åbo Akademi University, Vasa, Finland.

ORCID ID: https://orcid.org/0000-0002-4615-0747

Contact Address: isik.ulubas@abo.fi 